\title{
Subtitling Practice: From Translation to Transcreation
}

\author{
Evgeniya D. Malenova* \\ F.M. Dostoyevsky Omsk State University \\ 55 Mira, Omsk, 644077, Russia
}

Received 15.09.2016, received in revised form 01.12.2016, accepted 03.02.2017

For the past decade the issue of audiovisual translation (AVT) has been taking attention of both Russian and foreign language professionals, although most of Russian researchers concentrated on a textual aspect of audiovisual productions. However, the research paradigm shift in modern Russian Translation Studies requires developing of new research tools and methods, together with original translation strategies, which can be successfully applied during translation process, particularly in case of AVT. The aim of the present research is to study one of the most contradictive translation strategies - a strategy of transcreation, which has always been considered as the tool, used only by copyrighters dealing with domains of marketing and advertising. The author argues that the strategy of transcreation can be effectively used in the context of constrained translation, particularly in case of subtitling, defines the challenges of constrained translation and outlines the solutions that can be made using the strategy of transcreation.

Keywords: translation, transcreation, audiovisual translation, subtitling, translation strategy.

DOI: 10.17516/1997-1370-0060.

Research area: philology.

\section{Introduction}

We can hardly imagine our modern world without audiovisual products. Every time we turn on the TV, browse the Internet or go outside our homes, we dive into the depths of audiovisual content. Although viewers do not always think about it, the bulk of audiovisual productions are translated into Russian from other languages. According to the open sources, 302 out of 391 films that were shown in Russian cinemas in 2015 were originally filmed in some foreign language and had to be translated into Russian (Istoriya kinoprokata. Rossia, 2015). Moreover, if we take into consideration most of TV channels, it will become obvious that the amount of translated audiovisual content broadcasted every day can hardly be estimated.

Such an intensive flow of audiovisual content across language borders requires much effort to help native viewers understand all ideas, concepts and meanings conveyed by means of audiovisual entity, composed of four discursive channels: the verbal audio channel, the nonverbal audio channel, the non-verbal video channel and the verbal video channel (Gottlieb, 1997, cited in Pedersen, 2010:68). Thus, we cannot consider the

C) Siberian Federal University. All rights reserved

* Corresponding author E-mail address: malenovae@mail.ru 
audiovisual text as a verbal text; all mentioned discursive channels comprise an elaborate polysemiotic complex, the parts of which are interconnected and cannot be separated in the course of translation. Consequently, we are in great need of defining and researching some translation strategies, tools, and techniques, which will be effective in case of dealing with such entities of polysemiotic nature.

\section{Russian translation studies: a paradigm shift}

For quite a long period, Russian theoretical and applied Translation Studies have been concentrating upon a so-called text-focused approach to the translation process. The source text (ST) acted as a focus of research, while the target text (TT) should have been perceived in conformity with adequacy and formal fidelity requirements. It is against this background that researchers in the field used to treat AVT as a form of literary translation or conference interpretation, because they saw audiovisual text only as an element of written speech. Most of papers and theses concentrated upon research of "film dialogue" (Gorshkova, 2007), "film text" (Snetkova, 2009), "film translation" as a kind of literary translation (Fedorova, 2009). Thus, the audiovisual production's texture was separated into two layers: the film itself as a complex polycode and multilevel entity, and the film dialogue as a verbal component of the film. Such text-focused view narrowed the field for AVT research and failed to provide an efficient methodology, which could be used for a complex analysis of AVT.

Nowadays we can witness a total paradigm shift in the field of Russian translation studies. Researchers start criticizing the textoriented approach and abandon it in favor of communicative-functional approach. According to this approach, "any act of translation must be viewed in the context of the communication environment that includes the author of the ST, or sender, the receivers (recipients) of the ST, the translator, and the receivers of the TT (communication actors)" (Sdobnikov, 2011:1445). In other words, the emphasis is made not on the collision of source and target texts, but on a correspondent communicative situation, as well as goals and intentions of communication actors. This new direction of studies stipulates a necessity to develop completely new methodology tools, which will allow us to deal with the translation not as a "frozen" text, but as a product that functions in one or another area of human activity. I will argue that the communicativefunctional approach is the only way to research the phenomenon of AVT.

\section{Subtitling as a constrained translation}

Any audiovisual text should be treated as a polysemiotic complex, involving interaction of verbal and visual components of a film. This complexity is sometimes responsible for difficulties in comprehension of the film, because besides the discursive channels, mentioned above, each viewer has his or her own "mental" or "cognitive" channel, comprising feelings, emotions and associations evoked by the film plot, dialogues, music, etc., and influencing the process of viewer's perception. In the case of subtitling, we are deliberately adding one more element of this complex, which can substantially complicate the process of the film percipiency and sometimes draw the viewer's attention from some essential plot twists, visual effects, etc. Jorge Diaz Cintas and Aline Remael define subtitling as "a translation practice that consists of presenting a written text, generally on the lower part of the screen, that endeavors to recount the original dialogue of the speakers, as well as the discursive elements that appear in the image (letters, 
inserts, graffiti, inscriptions, placards, and the like), and the information that is contained on the soundtrack (songs, voices off) (Diaz Cintas, Remael, 2007:15). Such a complexity of subtitles together with potentially hampered perception, as mentioned above, impose many constraints upon a translator.

AV-translator, as any person involved into communication process, is bound hand and foot both by internal (personal) constraints, and external (contextual, environmental) constraints (Zabalbeascoa, 2010:27). The term "constrained translation" was first introduced by Christopher Titford, in his research concerned with translation of subtitles. Titford suggested that all challenges occurring in the process of subtitling "derive essentially from the constraints imposed on the translator by the medium itself" (Titford, 1982, sited in Diaz Cintas, 2004). This concept was further elaborated by Mayoral, Kelly and Gallardo, who defined two circumstances that remove the condition of freedom in AVtranslation, namely: a) the existence of various systems of communication; b) change of a channel (e.g. from the visual channel for the source text to the aural channel for the target text) (Mayoral, Kelly, Gallardo, 1988:363). Most of constraints that the translator faces during AVT can be called universal, because they can also be applied to the translator's work in general. For example, internal constraints, connected with self-discipline, background knowledge, way of perception, can limit the translator's freedom in the process of any type of translation. Most of translators often face external constraints, such as economic issues, cultural and social peculiarities, deadlines, dealing with different systems of communication, etc. All these constraints can be easily defined and researched in the frameworks of the communicative-functional approach. Although, in case of subtitling, the translator also meets some unique technical restrictions, imposed by the client, as well as general requirements concerning subtitles quality.

Let us consider said unique restrictions that make subtitling a constrained translation. Jan Pedersen points out three constraints of subtitling: spatial constraints, temporal constraints, and constraints stipulated by a semiotic switch from spoken to written language. (Pedersen, 2011:18). Spatial constraints are due to the peculiarities of subtitles' location on the screen. Generally speaking, the translator has only two lines with a limited number of characters that cannot be overpassed. The exact number of characters in a line usually depends on the clients' requirements, types of the devices to be used by the viewer, and many other factors. Different scholars talk about different number of characters to be fit in a line, but currents practice shows that the average amount of characters per line is 36 , thus making it 72 characters per 2 lines of a single subtitle. Temporal constraints are connected with the reading speed of the viewer. This means that the subtitle should stay on the screen for a definite amount of time for the viewer to be able to read it. It also varies according to the client's requirements and the type of a translation project. Henrik Gottlieb proposed the so-called " $12 \mathrm{CpS}$ rule", meaning that the subtitle, having two lines of 36 characters each, should stay on the screen for 6 seconds; total amount of 72 characters divided by 6 seconds gives us 12 characters per second (Gottlieb, 2001, sited in Pedersen, 2011:20). Nevertheless, the number of $12 \mathrm{CpS}$ is quite approximate, because the reading speed depends on the type of the audience (teenagers read faster than adults); type of syntactical structures used by the translator (complicated syntax makes the viewer read slower); amount of culture specific references in the film (the viewer needs additional time to understand these references); communicative situation and video context (in case of action-packed scenes the 
viewer switches attention to another channels, so the reading speed may decrease substantially); and so on and so forth.

One more constraint is superimposed by the very nature of subtitles translation, which was characterized by Gottlieb as "diagonal translation". It means that if in case of written or oral translation we often go in a horizontal direction: from ST as a written speech to TT as a written speech, or from ST as an oral speech to ST as an oral speech. Therefore, the translation is performed in one dimension. In case of subtitling the translator has to transform the oral speech of the ST into the written speech in the $\mathrm{TT}$, thus going "diagonally" from one dimension to another (Gottlieb, 1994:104). Moreover, I can add that dialogues in the film, play, TV-series or cartoon differ from spontaneous everyday speech, constructing a kind of "ideal" communicative situation. The thing is that all dialogues performed on the screen or on stage, as well as video sequences, music, actors' movements, noises, etc. are composed and compiled by the screenwriters, checked and edited by the directors and producers, rehearsed by the actors. Thus, the translator has to deal with a "disguised" (sometimes "artificial") written speech, presented as an oral speech. And in case of subtitling he or she has to convert it back into written speech. Therefore, in this case we can call it a "zigzaz translation". Taking into consideration all the above said it becomes clear that the translator of subtitles has to implement some special strategies to cope with all these constraints and requirements.

\section{Transcreation vs. translation}

The term "transcreation" is a merger of two words - translation and creation. Usually transcreation is perceived as "the creative adaptation of marketing, sales and advertising copy in the target language. It involves changing both words and meaning of the original copy while keeping the attitude and desired persuasive effect" (Branded Translations). The process of transcreation is usually set against the process of translation according to the following principles:

- The source content for transcreation is a creative text, including images, posters or commercials. In case of translation, the source text is some content copy or a digital asset.

- Translation and transcreation require different people with different skills: translators translate, and copywriters transcreate.

- Transcreation projects take more time than translation projects due to difference in billing and process itself (Donkor, 2015).

In other words, in the world of marketing and advertising transcreation is believed to be something more than translation, a process that "gives an added value to a job that would otherwise be subject to translation" (Pedersen, 2014:62).

Other researchers and language professional are not so positive about this battle between translation and transcreation. According to Elena Di Giovanni, the origin of the term "transcreation" goes back to the distant past, when it was used to describe techniques of creative translation of Indian sacred texts from Sanskrit. "This process allowed for a number of even radical changes to the original texts, which went well beyond the concept of 'translation proper' as it was and is still perceived within translation studies. The transcreated text had to be entirely fluent and, most importantly, it had to be fully understandable to its target audience" (Di Giovanni, 2008:33). Else Ribeiro Pires Vieira in her "Readings of Antropofagia and Haroldo de Campos' poetics of transcreation" also supports the idea that transcreation is a kind of translation strategy, that "demythicizes the ideology of fidelity” (Vieira, 1999:110). Thus, from the very beginning, transcreation has been closely connected to the translation process and was 
perceived as transformative recreation of the ST, "referred it to practices of transfer which involve the constitution of new texts and new realities" (Di Giovanni, 2008:34).

There is little doubt that translator is always acting as a creative agent, trying to bridge a gap between two languages and two cultures. The aim of any audiovisual production, as well as of a computer game, fiction book, theatrical performance, etc. is to provide a positive experience to the recipient. Thus, the translators should sometimes be given a kind of "freedom" to modify the TT in accordance with the recipients' anticipations. "And, in so doing, the traditional concept of fidelity to the original is discarded" (Mangiron, O'Hagan, 2006:20). Getting closer to AVT, Serenella Zanotti, who investigated processes of translation and transcreation in the course of dubbing, reports that in case of AVT the changes that dialogues undergo in the process of dubbing "are sometimes so radical and unpredictable that the notion of transcreation may be usefully called into question" (Zanotti, 2014:131).

Summarizing the above, we can argue that transcreation has a full right to be considered as translation strategy, in which creative approach dominates over the fidelity to the source text. Taking into consideration the concept of subtitling as a constrained translation, my idea is that transcreation can be successfully used in AVT as one of subtitling strategies aimed at transition of the elements of polysemiotic complex and used to overcome challenges, rooting in the constraints superimposed.

\section{Transcreation in subtitling: a case study}

Transcreation serves as the translation strategy in especially difficult subtitling cases, when common tools simply do not work. One of the examples is British TV series "Line of
Duty", produced by BBC. "Line of Duty" is a British police procedural television series created by Jed Mercurio that premiered on 26 June, 2012. It is a drama about the investigations of $\mathrm{AC12}$, a controversial Police Anti-Corruption Unit. This translation project is a good example of a set of different constraints, including quite strict technical requirements of the client, who treats subtitles as a primary asset. The client's priority is accurate and natural translations that make the source content available for millions of target language viewers. The other thing is that the client, as any broadcasting company that deals with subtitled content, wants its viewers not to read, but to watch a subtitled production without reminding them, that they are actually reading. Unnatural and syntactically complicated subtitles pull the viewer out of the viewing experience instead of supporting this experience. That is why so much attention is payed not only to the technical constraints, but to the quality of translation itself.

Talking about the case of "Line of Duty" series, it is important to mention technical requirements for subtitles: the required reading speed is $15 \mathrm{CpS}$, maximum length of a line is 36 characters, frame gap (a pause between subtitles) is 2 frames. The series proves to be quite a challenging material due to several factors. Firstly, the characters' speech speed is very high; in the original subtitles the reading speed is $1.5-2$ times higher than the one required by the client. Secondly, the dynamic plot and a fast cutting become another challenge for the translator. The scenes change rather fast, each episode is actionpacked; together with the high speech speed, it makes the translator use TT compression to encapsulate the ST meaning into 72 characters. Lastly, the TV series is full of culture specific references (CSR) that have no equivalents in the target language (toponyms, names of official ranks, names of activities, performed by the 
police, etc.). In some cases, using the strategy of transcreation was the only way of coping with all said challenges. Let us have a more detailed insight into the challenges of this translation projects and solutions, found thanks to the strategy of transcreation:

Challenge: Number of characters per original subtitle line corresponds with the technical requirements, but in case of following the formal fidelity in the course of translation, the number of characters in the target subtitle line exceeds the required one dramatically.

Solution: Create a new line, taking into consideration the situational equivalence and the series context.

It this case the translator faces a problem of grammatical category of gender. Though it is not a problem to translate the line "I've done one" into Russian, the second line is quite a challenging one, because the only equivalent for an English "female copper" (13 characters) is "женщинаполицейский” (back translation - "the womanpolicemen"), that makes it 19 characters, so the line becomes 6 characters longer (see Table 1). The situation on the screen is quite informal, the main character who takes part in the dialogue and the murdered female copper used to be friends, so that in Russian she turns into "подружку" ("she-friend"). Moreover, this murdered copper has been mentioned several times before in the current and previous episodes, so the subtitler does not confuse the viewer. This change causes further transformation of the line, thus "I've done" is translated as “на небесах" ('in Heaven'), and a threat to kill the main character is transformed into the invitation to join the deceased friend.

Challenge: Number of characters per original line exceeds the required limit, thus in case of following formal fidelity in the course of translation, the number of characters in the target line exceeds the required limit as well.

Solution: Create a new line in a target language that changes the meaning of the original line, but corresponds to the situation on the screen.

On the screen, we can see the police officers who arrived at the place of the ambush, organized - as they believe - by their colleague Lindsay Denton. We can hear the first line from a walkie-talkie, it is an all-points bulletin, a radio message sent to every officer in a police force giving details of Denton. The message is delivered in quite an official style, which must be followed during translation process. Although the second line is a reaction of the character, a police officer, to this message. This lady-officer knows Denton and is perfectly sure that Lindsay is guilty. In the course of translation a completely new line is created in accordance with target language rules that expresses the character's approval of the description, given in the bulletin (see Table 2).

Challenge: The character's speech speed exceeds required reading speed dramatically.

Solution: Partially transcreate the line, following the dialogue context

Table 1

\begin{tabular}{|c|c|}
\hline Source & Target \\
\hline $\begin{array}{c}\text { I've done one female copper. } \\
\text { Don't think I won't do another. }\end{array}$ & Твоя подружка уже на небесах. \\
Вочешь к ней?
\end{tabular}


Table 2

\begin{tabular}{|c|c|}
\hline Source & Target \\
\hline $\begin{array}{l}\text { 'Denton is known to employ } \\
\text { misrepresentation and deceit.' }\end{array}$ & $\begin{array}{c}\text { Дентон способна намеренно } \\
\text { ввести в заблуждение. }\end{array}$ \\
\hline $\begin{array}{l}\text { Well, I couldn't have put it } \\
\text { better myself. }\end{array}$ & Вот, этим всё сказано. \\
\hline \multicolumn{2}{|c|}{ Back translation (RU-EN) } \\
\hline \multicolumn{2}{|c|}{$\begin{array}{c}\text { Denton is able } \\
\text { to mislead deliberately. }\end{array}$} \\
\hline \multicolumn{2}{|c|}{ That's about all. } \\
\hline
\end{tabular}

Table 3

\begin{tabular}{|c|c|}
\hline Source & Target \\
\hline $\begin{array}{l}\text { They've charged you, remanded you. } \\
\text { What've they got on you? }\end{array}$ & $\begin{array}{c}\text { Суд, тюряга. } \\
\text { Что у них на тебя есть? }\end{array}$ \\
\hline \multicolumn{2}{|c|}{ Back translation (RU-EN) } \\
\hline $\mathrm{Wh}$ & \\
\hline
\end{tabular}

On the screen, we can see corrupted police officers, who kidnapped Lindsay Denton and are trying to find out, what she had said to the police. The dialogue is dramatized in quite a rude manner; the interrogator punches the main character in the face. The scene is emotionally packed; the speech speed is very high. In this case, the translator has to shorten the first line of the subtitle by developing the meaning of the source line (see Table 3). The actions ("charged you", "remanded you") are changed for the names of locations, where they were performed ("суд", “тюряга" (“court", “prison”)). As the result, the target subtitle is shortened, reading speed is modified as needed, and the meaning and tonality of the dialogue is not distorted.

Challenge: Source reading speed exceeds the required one.

Solution: Transcreate the dialogue completely, following the dialogue and series contexts.

On the screen, we can see Lindsay Denton talking to her friend, a police officer, DS Steve
Arnott, who is driving a car. Lindsay is talking quickly and emotionally, because her life depends on the result of this discussion. That is why the atmosphere on the screen is quite intense and long, complicated subtitles will distract the viewer.

In the example given (see Table 4) the translator decides to transcreate the whole part of the monologue in accordance with its context, communicative situation and the series' plot. The original utterance contains a lot of hidden pitfalls that become real challenges for the translator: the term "driving offence" that can be translated into Russian by a much longer equivalent "нарушение правил дорожного движения" ("breaking the road traffic regulations"), which contains too many characters for the subtitle; the idiom "to melt away"; the cultural specific concept "DCC" (Deputy Chief Constable), the second highest rank in all territorial police forces in the United Kingdom, which has no direct equivalent in the Russian language. As consequence, the parts of the utterance change their places, name of the rank is changed for an 
Table 4

\begin{tabular}{|l|c|}
\hline \multicolumn{1}{|c|}{ Source } & Target \\
\hline $\begin{array}{l}\text { He's been accused of lying } \\
\text { about a driving offence, } \\
\text { and it's all just melted away. } \\
\text { it's nothing to do } \\
\text { with him being the DCC? }\end{array}$ & $\begin{array}{c}\text { Помнишь тот случай с аварией? } \\
\text { и вышел сухим из воды. }\end{array}$ \\
\hline \multicolumn{2}{|c|}{ Он - большая шишка. } \\
\hline \multicolumn{2}{c}{$\begin{array}{c}\text { Remember that accident? } \\
\text { He gave false testimony } \\
\text { and came off the hook. } \\
\text { He's a big wheel. }\end{array}$} \\
\hline
\end{tabular}

Table 5

\begin{tabular}{|c|c|}
\hline Source & Target \\
\hline Kate, will you do that, anyway? & Кейт, оформляйте задержание. \\
\hline \multicolumn{2}{|c|}{ Back translation (RU-EN) } \\
\hline \multicolumn{2}{|c|}{ Kate, take her into custody. } \\
\hline
\end{tabular}

Table 6

\begin{tabular}{|c|c|}
\hline Source & Target \\
\hline $\begin{array}{c}\text { Where are you? } \\
\text { 'The old Highpoint Building. }\end{array}$ & $\begin{array}{c}\text { Где вы? } \\
\text {-В Хайгете. }\end{array}$ \\
\hline $\begin{array}{c}\text { Highpoint's over in Moss Heath. } \\
\text { You need to make a U... }\end{array}$ & $\begin{array}{c}\text { Хайгет в другой стороне. } \\
\text { Тебе придётся... }\end{array}$ \\
\hline \multicolumn{2}{|c|}{ Back translation (RU-EN) } \\
\hline High & \\
\hline
\end{tabular}

idiom "большая шишка" ("big wheel”), but the context and tonality of the dialogue remain the same. The situation of DCC's lying is translated in accordance with the macrocontext of the series, because the whole episode was describing this situation, so the viewer can easily perceive mentioning of this plot twist.

Challenge: The source subtitle may be confusing the viewers.

Solution: Create a new line and clarify the meaning.
In the example (see Table 5), the subtitle is separated from the context of the dialogue by some scenes. The viewers watching the original version of the series can easily understand the meaning of the line, though the ones watching the subtitled version can be confused with the literal translation of the line and never understand, what Kate is to do. So the translator transcreates the original line by narrowing its meaning to define a specific action. 
Challenge: Culture specific references (CSRs) that are impossible to be translated using literary translation and following technical restrictions.

Decision: Transcreate the line using other CSRs, following the situation on the screen and keeping required reading speed.

There are many CSRs in the example given (see Table 6). Firstly, it is a reference to the Highpoint Building, the first apartment block in London, constructed in 1935. Highpoint building is usually regarded as the best work, being the first authoritative example of international modern architecture in England. Most of Russian viewers have no idea of this building, so the decision is taken to change the name of the building into the name of the district - "Хайгет" ("Highgate"), where it is located. Secondly, the character mentions another toponym - "Moss Heath" - that is hard to recognize even for the native speakers; this is what they say in the comments to the second season of the series. But the next line contains an abbreviation $U$ meaning an U-turn - "a turn that you make while driving a car, walking, etc., that causes you to begin going in the opposite direction: a 180-degree turn" (Merrian-Webster). We can make a conclusion that the characters, who are driving in a search of Lindsay Denton, are moving in an opposite direction. Mentioning of the need to make a U-turn is not important for the subtitle, because the next second the police officer that heard the words of his partner takes an unexpected turn, crudely violating traffic regulations. It is also necessary to mention that this scene is very dynamic itself; the characters are driving fast in the pursuit of Lindsay Denton and are talking very fast as well. That is why there is one more task for the translator, which is making the subtitle as short as possible not to draw the viewers' attention from the situation on the screen.

\section{Conclusions}

The aim of the current research was to provide tangible evidence that some challenges, appearing due to the constrained nature of subtitling, can be addressed effectively by implementing the strategy of transcreation. As the case study shows, transcreation can be very helpful in case of subtitling, because it allows to easily compensate for losses inevitable, due to technical constraints and high speech speed. In some cases, the changes made were quite radical and unexpected, so the translator sometimes became a co-author of the screenwriter. From the point of view of communicative-functional approach, transcreation may become a very important tool for reaching the goals and intentions of both the TT senders and ST recipients, because it proves to be an effective instrument to provide a positive experience to the viewers together with following all restrictions and dealing with all constraints of subtitling process.

As the result of the case study transcreation in AVT can be defined as a strategy of creative rethinking of a source text segment with subsequent generation of a totally new target text segment in conformity with the given $\mathrm{AV}$ context as a polysemiotic complex, taking into consideration characteristics of the communicative situation, technical constraints and an anticipated response of the spectators. The research can be continued in the aspect of studying transcreation mechanisms and researching transcreation with regard to other types of AVT.

\section{References}

Branded Translations. Transcreation. Available at: http://www.brandedtranslations.com/ transcreation/ (accessed August 20, 2016) 
Di Giovanni, E. (2008). Translations, Transcreations and Transrepresentations of India in the Italian Media, In Meta: Translators' Journal. 53 (1). 26-43. Available at: http://id.erudit.org/ iderudit/017972ar (accessed August 20, 2016).

Diaz Cintas, J, Remael, A. (2007). Audiovisual Translation: Subtitling. Manchester, St. Jerome Publishing. 272 p.

Diaz Cintas, J. (2004) Subtitling: the long journey to academic acknowledgement. In The Journal of Specialized Translation (JoSTrans). Available at: http://www.jostrans.org/issue01/art_diaz_cintas. php (accessed August 19, 2016)

Donkor, L. (2015). Three differences between transcreation and translation. Available at: https:// www.welocalize.com/three-differences-between-transcreation-and-translation/ (accessed August 20, 2016).

Fedorova, I.K. (2009) Perevod kinoteksta v svete konztepztii kulturnogo perenosa: problema perevodcheskoy adaptatzii [Film text translation as a cultural transfer: translation adaptation issues], In Vestnik Chelyabinskogo Gosudarstvennogo Universiteta. Filologiya. Iskusstvovedeniye [Bulletin of Chelyabinsk State University. Philology. Art Studies], 43 (181), 39. 142-149.

Gorshkova, V.E. (2007). Perevod v kino: dublirovanie vs. subtitry (na materiale filma Luca Bessona “Angel-A", Frantsia, 2005) [Film translation: dubbing vs. subtitling (case study of Luc Besson's “Angel-A”, France, 2005], In Vestnik NGU. Seria: Lingvistika I Mezhkulturnaya Kommunikatsia [Bulletin of NGU. Linguistics and Intercultural Communication], 5, 1, 133-140.

Gottlieb, H. (1994) Subtitling: diagonal translation. In Perspectives: Studies in Translatology. 2 (1). 101-121.

Istoriya kinoprokata. Rossia (2015) [Film distribution history. Russia]. Available at: http://www. kino-teatr.ru/box/history/ru/y2015/ (accessed August 18, 2016)

Mangiron, K., O’Hagan M. (2006) Game localization: unleashing imagination with 'restricted' translation, In The Journal of Specialized Translation. 6. 10-21.

Mayoral, A., Kelly, D., Gallardo, N. (1988). Concept of constrained translation. Non-linguistic perspectives of translation. Meta: Translators' Journal. 33(3). 356-367.

Merriam Webster: Dictionary and Thesaurus. Available at: http://www.merriam-webster.com/ dictionary/u\%20turn (accessed August 20, 2016)

Pedersen, D. (2014) Exploring the concept of transcreation - transcreation as "more than translation"? In Cultus: the Journal of Intercultural Mediation and Communication. Transcreation and the Profession. Bologna-Italy. 7. 57-71.

Pedersen, J. (2010). When do you go for benevolent intervention? How subtitlers determine the need for cultural mediation, In New Insights into Audiovisual Translation and Media Accessibility. Media for All 2. Amsterdam - New York, NY, 67-80.

Pedersen, J. (2011). Subtitling norms for television: an exploration focusing on extralinguistic cultural references. Amsterdam - Philadelphia. John Benjamins Publishing Company. 242 p.

Sdobnikov, V.V. (2011) Translation Strategy Revised: the Communicative-Functional Approach, In Journal of Siberian Federal University. Humanities \& Social Sciences. 10 (2011 4), 1444-1453.

Snetkova, M.S. (2009). Lingvostilisticheskie aspekty perevoda inspanskikh kinotekstov na materiale perevodov khudozhestvennykh filmov L. Bunuelya "Veridiana” i P. Almadovara "Zhenshiny na Grani Nervnogo Sryva” [Linguo-stylistic aspects of translation of Spanish film texts: a study of 
translations of motion pictures "Veridiana" by L. Bunuel and "Women on the Verge of a Nervous Breakdown" by P. Almodovar]. Candidate of Philology Thesis. Moscow, 232 p.

Vieira, E. (1999) Readings of Antropofagia and Haroldo de Campos' poetics of transcreation, In Post-colonial translation, London, Routledge. 95-113.

Zabalbeascoa, P. (2010) Translation in constrained communication and entertainment, In New Insights into Audiovisual Translation and Media Accessibility. Media for All 2. Amsterdam - New York, NY, 25-40.

Zanotti, S. (2014) Translation and Transcreation in the Dubbing Process: a Genetic Approach, In Cultus: the Journal of intercultural mediation and communication. 7. 107-132.

\title{
Проблемы перевода субтитров:
}

\section{от перевода к транскреации}

\section{Е. Малёнова \\ Омский государственный университет им. Ф.М. Достоевского Россия, 644077, Омск, пр. Мира, 55}

\begin{abstract}
В последние годы проблемы аудиовизуального перевода (АВП) вызывают все больший интерес как у зарубежных, так и у отечественных лингвистов. Большая часть российских исследований, посвященных проблемам АВП, выполнена в русле текстоориентированного подхода, поэтому коренное изменение парадигмы отечественных научных исследований в области теории перевода и переориентациии на коммуникативно-функциональный подход обусловливает необходимость в разработке нового методологического инструментария и переводческих стратегий, которые можно было бы успешно применять в процессе АВП. Цель настоящего исследования - рассмотреть одну из наиболее противоречивых переводческих стратегий стратегию транскреации - применительно к переводу субтитров. Автор предполагает, что данная стратегия может эффективно использоваться в условиях ограниченного перевода, которым и является перевод субтитров, выявляет переводческие проблемы, вызванные наличием ограничений, и предлагает решения, обусловленные возможностью применения стратегии транскреации.
\end{abstract}

Ключевые слова: перевод, транскреация, аудиовизуальный перевод, субтитрирование, стратегия перевода.

Научная спечиальность: 10.00 .00 - филологические науки. 